\title{
Efektifitas Belajar Fisika Mahasiswa Melalui Program Pembelajaran Fisika Berbasiskan ICT
}

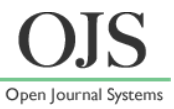

\author{
Afrizal Mayub \\ Pascasarjana Pendidikan IPA FKIP Universitas Bengkulu \\ *E-mail: afrizalmayub@unib.ac.id
}

DOI: https://doi.org/10.33369/pendipa.5.1.40-49

\begin{abstract}
[The Effectiveness of Students' Physics Learning Through ICT-Based Physics Learning Program]. This research aims to; Producing an ICT-Based Physics Learning Program Package, (2) Describing the effectiveness of Physics Learning using the ICT-Based Physics Learning Program, (3) Describing the effectiveness level of Physics Learning using the ICT-Based Physics Learning Program and (4) Describing the role of the ICT-Based Physics Learning Program in motivating learning students, reduce student misconceptions and a forum for the development of students' dual intelligence. The research method is divided into two parts. First, the pre-research activity is to create an ICT-based Physics Learning Program which includes: Analysis, Design, Code, and Testing. The second is research to see the effectiveness of the ICT-Based Physics Learning Program in learning. Besides that, it also analyzes its effect on learning motivation, decreasing misconceptions and a place where student intelligence grows. Sampling using total sampling technique. Based on this, the researchers determined that a sample of all master science students in semester 1 and 3 of the 2019/2020 academic year was 54 people. The results showed that, the ICTbased Physics Learning Program was effectively used in learning, it was seen from the $N_{\text {Gain }}$ value of 0.82 which was in the high or very effective category. The ICT-based Physics Learning Program is effectively used to motivate students to learn it can be seen from the motivation score of 3.88 (from a scale of 1-4) is in the very good category. The ICT-based Physics Learning Program is effectively used as a place for the development of students' dual intelligence, it can be seen from the score obtained of 3.94 (from a scale of 1-4) is in the very good category. The ICT-based Physics Learning Program is effectively used to reduce student misconceptions, it can be seen from the misconception reduction score of 3.94 (from a scale of 1-4) is in the very good category.
\end{abstract}

Keywords: effectiveness, multiple intelligence, misconceptions, motivation, ICT.

\begin{abstract}
ABSTRAK
Penelitian ini bertujuan untuk; (1). Menghasilkan Paket Program Pembelajaran Fisika Berbasiskan ICT, (2) Mendiskripsikan efektivitas Pembelajaran Fisika menggunakan Program Pembelajaran Fisika Berbasiskan ICT, (3) Mendiskripsikan tingkat efektivitas Pembelajaran Fisika menggunakan Program Pembelajaran Fisika Berbasiskan ICT dan (4) Mendiskripsikan peran Program Pembelajaran Fisika Berbasiskan ICT dalam memotivasi belajar mahasiswa, menurunkan miskonsepsi mahasiswa dan wadah pengembangan inteligensi ganda mahasiswa. Metode penelitian dibagi menjadi dua bagian. Pertama, Kegiatan Pra penelitian yaitu membuat Program Pembelajaran Fisika Berbasiskan ICT yang meliputi: Analysis, Design, Code, dan Testing. Kedua adalah penelitian untuk melihat efektivitas Program Pembelajaran Fisika Berbasiskan ICT dalam pembelajaran. Selain itu dianalisa juga pengaruhnya terhadap motivasi belajar, penurunan miskonsepsi dan wadah tempat tumbuh-kembangnya inteligensi mahasiswa. Pengambilan sampel menggunakan teknik total sampling. Berdasar hal itu peneliti menetapkan sampel semua mahasiswa S2 IPA semester 1 dan 3 tahun ajaran 2019/2020 sebanyak 54 orang. Hasil penelitian memperlihatkan bahwa, Program Pembelajaran Fisika Berbasiskan ICT efektif digunakan dalam pembelajaran, hal itu terlihat dari nilai $N_{\text {Gain }}$ sebesar 0,82 berada dalam kategori tinggi atau sangat efektif. Program Pembelajaran Fisika Berbasiskan ICT efektif digunakan untuk memotivasi mahasiswa belajar hal itu terlihat dari score motivasi sebesar 3,88 (dari Skala 1-4) berada dalam kategori sangat baik. Program Pembelajaran Fisika Berbasiskan ICT efektif digunakan sebagai wadah tumbuh-kembangnya inteligensi ganda siswa, hal itu terlihat dari score yang didapat sebesar 3,94 (dari Skala 1-4) berada dalam kategori sangat baik. Program Pembelajaran Fisika Berbasiskan ICT efektif digunakan untuk
\end{abstract}


menurunkan miskonsepsi siswa, hal itu terlihat dari score penurunan miskonsepsi sebesar 3,94 (dari Skala 1-4) berada dalam kategori sangat baik.

Kata Kunci: Efektifitas, inteligensi ganda, miskonsepsi, motivasi, ICT.

\section{PENDAHULUAN}

Ilmu Fisika merupakan ilmu yang relatif abstrak, sehingga sukar membayangkan, akibatnya sebagian mahasiswa langsung saja menyelesaikan masalah fisika dengan rumusrumus, tanpa berusaha terlebih dahulu memahami latar belakang falsafah yang mendasarinya, hal iniu menyebabkan mata ajaran Fisika kurang diminati. Sehingga mahasiswa ada yang mengalami kesulitan dalam belajar fisika (Sutrisno:1993). Komputer dapat menampilkan konsep-konsep fisika yang abstrak menjadi nyata dengan visualisasi statis maupun dengan visualisasi dinamis (animasi). Selain itu komputer dapat membuat suatu konsep lebih menarik sehingga menambah motivasi untuk mempelajari dan mengusainya. Sejalan dengan hal diatas hasil belajar mahasiswa untuk matakuliah Fisika (Listrik magnet, Mekanika dan Fisika Likngkungan) pada tiga kali priode pembelajaran (semester ganjil 2017/2018, semester genap 2017/2018, dan semester ganjil 2018/2019) belum menunjukan hasil yang optimal secara kualitaif maupun kuantitatif, hal itu disebabkan oleh banyak faktor diantaranya masih belum tercipta pembelajaran yang efektif, penyampaian bahan ajar kurang menarik dan mahasiswa kurang terlibat dalam pembelajaran sehingga pembelajaran kurang diminati dan kurang efektif.

Agar tercipta suasana menyenangkan dalam belajar dan belajar efektif, materi ajar yang disampaikan haruslah mengikuti kaedah psikologis siswa, yaitu disusun secara urut dan sistematis serta dilengkapi dengan sistem multimedia yang baik. Kaedah-kaedah di atas direkayasa untuk memenuhi standar mutu yang telah ditetapkan. Untuk mewujudkan fungsi seperti di atas, perlu dirancang dan dibuat sistem pembelajaran yang menarik dan memenuhi standar, sehingga hasil pembelajaran peserta didik memenuhi standar yang telah dibuat yaitu tercapainya efektifitas belajar dan belajar bermakna yang ditandai oleh terciptanya efektifitas belajar pada kategori "sangat efektif" atau sekurang kurangya pada "kategori efektif".

Komputer sebagai sarana e-learning fisika adalah dimungkinkannya dibuat sistem multimedia yang interaktif, sehingga pengguna dapat bersifat aktif, selain bersifat reaktif atau pasif. Pengguna aktif disini diartikan adanya mekanisme yang memungkinkan pengguna memegang inisiatif dalam mempelajari fisika, bukan sekedar reaktif terhadap prompt yang diberikan oleh komputer (Sutrisno: 1993). Implikasi penggunaan teknologi informasi dan komputer dalam pembuatan model e-learning umumnya bersumber pada kondisi pembelajaran itu sendiri.

Kondisi yang dimaksud meliputi materi ajar fisika, fasilitas, model pembelajaran, mahasiswa, serta guru yang mengajar. Kenyataan yang ditemui di lapangan menunjukkan, ada mahasiswa yang kurang tertarik mempelajari fisika serta merasa sulit untuk memahami materinya, hal ini ditandai oleh masih rendahnya hasil belajar fisika mahasiswa. Pengertian suatu konsep dalam pembelajaran fisika sangat penting, untuk itu animasi yang dapat menunjukkan gejala fisis perlu diutamakan tanpa mengabaikan proses-proses lainnya. Oleh sebab itu Program Pembelajaran fisika berbais ICT yang ideal haruslah mampu berfungsi sebagai media presentasi informasi dalam bentuk teks, grafik, simulasi, animasi, latihan-latihan, analisis kuantitatif, umpan-balik langsung, aktif, reaktif, instruksi yang bersifat individual sesuai dengan kemajuan belajarnya, sehingga memberikan konsep yang benar pada mahasiswa.

Pembelajaran fisika berbais ICT merupakan salah satu terapan e-learning. Elearning didefinisikan sebagai suatu bentuk teknologi informasi yang diterapkan di bidang pendidikan berupa sekolah maya (Purbo., Hartanto., 2003). Namun secara umum difinisi $e$ learning adalah pembelajaran baik secara formal maupun informal yang dilakukan melalui media elektronik, seperti Internet, Intranet, Ektranet, CDROM, video tape, DVD, TV, Handphone, PDA dll (Team e-learning, 2004).

Dalam belajar sebaiknya motivasi intrinsik dikembangkan secara optimal agar efektivitas belajar mahasiswa dapat tercapai, karena motivasi tersebut bersumber dari dalam diri mahasiswa, sehingga secara psikologis daya dorongnya relatif stabil dan murni. Untuk mengembangkan motivasi 
tersebut E-Learning harus mampu menyuguhkan/menciptakan proses belajar yang bermakna, tuntas dan efektif. Siswa dikatakan sangan efektif dalam belajar bila nilai $\mathrm{N}_{\text {Gain }} \geq$ 0,7 (Sugiono, 2017). Disamping itu riset menunjukkan bahwa, Virtual Classroom mampu menyediakan beberapa opsi yang lebih menarik jika diimplementasikan dengan pendekatan yang tepat (Marie, 2009). Virtual Learning ini banyak diminati orang karena potensi yang dimilikinya telah dirasakan membuat proses belajar menjadi efektif (Haryono, 2012). Demikian pula riset di Waseda Jepang, menunjukkan bahwa $E$ Learning merupakan alat pembelajaran yang efektif. Penggunaan E-Learning signifikan karena taksonomi bloom menyediakan data pengukuran yang empiris untuk mengukur perbedaan antara pembelajaran menggunakan E-Learning dengan pembelajaran di kelas secara tradisional. Harus diakui bahwa taksonomi Bloom dapat memperluas lingkungan pembelajaran E-Learning, karena ada persamaan keistimewaan dan kemampuan masing-masing yang bersifat individu. (Laela Halawi dkk, 2010).

Kelas online cenderung menjadi sukses bila didasari oleh ilmu pedagogis dan penyusuan materi ajar yang benar (Mustaji., 2011). Pembelajaran e-learning membuat siswa leluasa belajar secara mandiri, mudah memahami yang abtrak, dan dapat melakukan praktikum secara virtual (Mustaji., 2011). Pembelajaran Fisika menjadi enak dikomsumsi mahasisawa bila dikemas dengan animasi yang baik dan benar (DePorter and Hernacki., 2011). Penggunaan komputer dapat menciptakan pembelajaran bermakna, pengelolaan pembelajaran yang efisien, dan penadministrasian siswa yang efektif (Morten Brekke, Per Henrik Hogstad., 2010). Demikian pula riset tentang penggunaan game dan animasi 3D untuk pembelajaran di SMP pokok bahasan "Bangun Ruang" menunujukkan bahwa Terdapat perbedaan hasil belajar yang signifikan antara pembelajaran menggunakan game dan animasi 3 D dengan pembelajaran konvensional. Respons siswa terhadap penggunaaan game dan animasi 3D dalan belajar lebih dari $70 \%$ atau tergolong tinggi (Yandri, 2009). Pengembangan Pembelajaran fisika dengan multiple Representations Berbasis ICT Meningkatkan penguasaan Konsep Kinematika, persepei yang baik dan motivasi yang baik (Ishafit, 2014).

Program Pembelajaran fisika berbais ICT harus mampu untuk "meng-konkretkan" konsep yang abstrak sehingga mudah dimengerti mahasiswa, hal ini dapat diwujudkan dengan bantuan komputer. Secara spesifik kajian dalam penelitian ini adalah (1) Efektifitas belajar Fisika melalui Program Pembelajaran Fisika Berbasiskan ICT, (2) Peran Program Pembelajaran Fisika Berbasiskan ICT dalam memotivasi belajar mahasiswa, menurunkan miskonsepsi mahasiswa dan wadah pengembangan inteligensi ganda mahasiswa. Berdasar uraian di atas dirumuskan permasalahan sebagai berikut "Bagaimana mengimplementasikan Program Pembelajaran Fisika Berbasiskan ICT untuk mengefektifkan belajar Fisika”, sehingga yang menjadi tujuan penelitian ini adalah (1) Menghasilkan Paket Program Pembelajaran Fisika Berbasiskan ICT, (2) Mendiskripsikan efektivitas Pembelajaran Fisika menggunakan Program Pembelajaran Fisika Berbasiskan ICT, (3) Mendiskripsikan tingkat efektivitas Pembelajaran Fisika menggunakan Program Pembelajaran Fisika Berbasiskan ICT dan (4) Mendiskripsikan peran Program Pembelajaran Fisika Berbasiskan ICT dalam memotivasi belajar siswa, menurunkan miskonsepsi siswa dan wadah pengembangan inteligensi ganda siswa.

\section{METODE PENELITIAN}

Bagian ini menguraikan proses penelitian mulai dari perencanaan Pengembangan Program Pembelajaran Fisika Berbasiskan ICT, pelaksanaan Program Pembelajaran Fisika Berbasiskan ICT. Pengembangan Program Pembelajaran Fisika Berbasiskan ICT, sampai pada uji efektivitas penggunaan Program Pembelajaran Fisika Berbasiskan ICT dan uji hipotesis. Secara sederhana tahap dan proses penelitian dibagi menjadi dua bagian. Pertama, Kegiatan Pra penelitian yaitu membuat Program Pembelajaran Fisika Berbasiskan ICT yang meliputi: Analysis, Design, Code, dan Testing. Kedua adalah penelitian untuk melihat efektivitas Program Pembelajaran Fisika Berbasiskan ICT daam pembelajaran. Selain itu dianalisa juga pengaruhnya terhadap motivasi belajar, penurunan miskonsepsi dan wadah tempat tumbuh-kembangnya inteligensi mahasiswa.

A. Pra Penelitian

1. Analisis Kebutuhan, Kegiatan ini meliputi, Analisis Kebutuhan Program Pembelajaran Fisika Berbasiskan ICT, Peranan mahasiswa dalam belajar, Interaksi dialog terarah mahasiswa dengan Program Pembelajaran Fisika Berbasiskan ICT, Skenario untuk membimbing 
dialog maya, dan Modul Pembelajaran yang diperlukan.

2. Desain; meliputi Desain Program ELearning, Desain Model analisis interaksi edukatif, dan Desain modul yaitu; Modul presentasi untuk materi, Modul animasi untuk demo, Modul analisis, Modul jawaban masalah, Modul ujian materi, Modul examination, Modul practice test, dan Modul program help.

3. Menulis Program dan

4. Uji coba Program Pembelajaran Fisika Berbasiskan ICT

B. Uji Efektifitas Program Pembelajaran Fisika Berbasiskan ICT

1. Populasi dan Sampel, Populasi merupakan keseluruhan objek yang diteliti, sedangkan sampel merupakan bagian populasi (Sulistyo, 2010). Pengambilan sampel disesuaikan dengan tujuan suatu riset. Riset ini bertujuan untuk mengetahui efektivitas Program Pembelajaran Fisika Berbasiskan ICT dalam pembelajaran fisika dasar mahasiswa S2 IPA FKIP UNIB. Pengambilan sampel menggunakan teknik total sampling. Berdasar hal itu peneliti menetapkan sampel semua mahasiswa S2 IPA smt 1 dan 3 tahun ajaran 2019/2020 sebanyak 54 orang.

2. Variabel, Variabel terdiri dari variabel bebas dan varibel terikat. Varibel bebas adalah Program Pembelajaran Fisika Berbasiskan ICT yang digunakan mahasiswa dalam belajar fisika, sedangkan variabel terikatnya adalah nilai kualitatif dan kuantitatif hasil belajar, motivasi, penurunan miskonsepsi dan wadah pengembangan inteligensi ganda mahasiswa.

3. Bahan dan Materi, Bahan ajar yang digunakan dalam penelitian ini adalah materi ajar fisika dasar topik Gerak Dua Dimensi yang meliputi Gerak Parabola, Gerak Satelit, dan Gerak Roket.

4. Alat bantu/instrumen

a. Soal tes yang diberikan bertujuan untuk mengetahui efektivitas penggunaan Program Pembelajaran Fisika Berbasiskan ICT dalam Pembelajaran Fisika. Soal tes disesuaikan dengan kompetensi yang dinginkan dalam pembelajaran. Penelitian ini menggunakan soal sebanyak 30 butir. Soal tes berfungsi mengukur kemampuan kognitif mahasiswa, meliputi ingatan, pemahaman, penerapan, dan analisis dengan komposisi yang cenderung membentuk kurva normal.

Tabel 3.1 Komposisi ranah kognitif yang diukur

\begin{tabular}{llcl}
\hline No & Ranah kognitif & $\sum$ Soal & $\sum \%$ \\
\hline 1 & petahuan/ingatan & 4 & $13,3 \%$ \\
2 & pemahaman & 11 & $36,7 \%$ \\
3 & penerapan & 10 & $33,3 \%$ \\
4 & analisis & 5 & $16,7 \%$ \\
\hline
\end{tabular}

b. Program Pembelajaran Fisika Berbasiskan ICT, dibagikan ke semua sampel untuk di pelajari dan setiap sampel/subjek penelitian diharuskan memberikan penilaian secara kualitatif dan kuantitatif mengenai fungsi Program Pembelajaran Fisika Berbasiskan ICT untuk memotivasi belajar, menurunkan miskonspsi siswa dan wadah pengembangan inteligensi ganda siswa dengan pedoman atau kreteria sebagai berikut

Tabel 3.2 Kriteria penilaian/score peran Program Pembelajaran Fisika Berbasiskan ICT terhadap motivasi, wadah inteligensi ganda, dan penurunan miskonsepsi siswa

\begin{tabular}{ccccl}
\hline No & Skor & Kriteria & Kategori kualitas \\
\hline 1 & 4 & $85-100$ & A & Sangat baik \\
2 & 3 & $75-84$ & B & Baik \\
3 & 2 & $60-74$ & C & Sedang \\
4 & 1 & $<60$ & D & Buruk \\
\hline
\end{tabular}

4. Cara mengumpulkan, mengolah, dan analisa data

a. Pengumpulan Data.

Hasil belajar. Data untuk menguji Konsep Fisika diperoleh dengan menggunakan soal yang diberikan kepada sampel. Test dilakukan dua kali, pretest dan postest. Penelitian ini menggunakan soal objektif sebanyak 30 butir dengan rentang skor minimum-maksimum 0 sampai 100.

Data motivasi belajar, penurunan miskonsepsi siswa dan wadah pengembangan inteligensi ganda siswa didapat dari subjek penelitian yang terdiri dari guru IPA SMA dan SMP. Subjek Penelitian memberikan skor motivasi belajar, penurunan miskonsepsi dan wadah pengembangan inteligensi ganda siswa yang diperan Program Pembelajaran Fisika Berbasiskan ICT yang dibagikan.

b. Mengolah data

Data hasil belajar mahasiswa terdiri dari hasil pretest dan postes, selanjutnya diolah dengan formula,

$$
\mathrm{N}_{\text {gain }}=\frac{\left(\mathrm{X}_{2}-\mathrm{X}_{1}\right)}{\left(\mathrm{X}_{3}-\mathrm{X}_{1}\right)}
$$


Besaran $x_{1}=$ skor pretest, $x_{2}=$ skor posttest dan $x_{3}=$ skor maksimum. Data memotivasi belajar, penurunan miskonspsi siswa dan wadah pengembangan inteligensi ganda siswa didapat dari subjek penelitian yang terdiri dari guru IPA SMA dan SMP selanjutnya diolah dengan menggunakan tabel 3.3

Tabel 3.3. Kriteria Pemberian score Program Pembelajaran Fisika Berbasiskan ICT

\begin{tabular}{|c|c|c|c|c|c|c|c|c|c|c|c|c|c|c|c|c|}
\hline \multirow[b]{2}{*}{ No } & \multirow[t]{2}{*}{ Subjek } & \multicolumn{4}{|c|}{ Kriteria } & \multicolumn{4}{|c|}{ Kategori } & \multicolumn{3}{|c|}{ Skor } & \multicolumn{4}{|c|}{ kualitas } \\
\hline & & $85-100$ & $75-84$ & $60-74$ & $<60$ & $\mathrm{~A}$ & B & $\mathrm{C}$ & & 4 & \begin{tabular}{l|l}
32 & 2 \\
3
\end{tabular} & 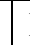 & $\mathrm{a}$ & $\mathrm{b}$ & $\mathrm{c}$ & $\mathrm{d}$ \\
\hline 1 & Memotivasi & & & & & & & & & & & & & & & \\
\hline 2 & Wadah inteligensi ganda & & & & & & & & & & & & & & & \\
\hline 3 & Menurunkan miskonsepsi & & & & & & & & & & & & & & & \\
\hline
\end{tabular}

Besaran $\mathrm{a}=$ sangat baik, $\mathrm{b}=$ baik, $\mathrm{c}=$ sedang dan $\mathrm{d}=$ buruk

c. Analisa data.

Efektivitas Penggunaan Program Pembelajaran Fisika berbasis ICT

Analisis Efektivitas Pembelajaran (NGain) Keefektifan model pembelajaran akan sulit diukur dari proses pembelajaran karena ada banyak hal yang perlu diamati. Cara yang paling mungkin dilakukan adalah mengukur peningkatan sejauh mana target tercapai dari awal sebelum perlakuan (tes kemampuan awal) hingga target hasil belajar setelah diberi perlakuan (post test). Target yang ingin dicapai tentunya $100 \%$ materi dikuasai siswa, dan minimal telah mencapai KKM (Kriteria Ketuntasan Minimum). Untuk menguji efektivitas pembelajaran menggunakan Program Pembelajaran Fisika Berbasiskan ICT digunakan perhitungan manual yaitu dengan rumus efektivitas $\mathrm{N}$ Gain sebagai berikut. N-Gain $=$ skor postest - skor tes kemampuan awal skor maksimum - skor Tes Kemampuan Awal (sugiyono, 2017. Keterangan: N-Gain = Gain yang ternormalisir Pre test $=$ Nilai awal pembelajaran Post test $=$ Nilai akhir pembelajaran.

Program Pembelajaran Fisika Berbasiskan ICT dikatakan efektif digunakan dalam pembelajaran fisika bila hasil post-tes mahasiswa lebih besar dari hasil pre-test $\left(\mathrm{X}_{2}>\right.$ $\mathrm{X}_{1}$ ) dan jumlah mahasiswa yang bernilai $\geq 70$ $\geq 80 \%$. Sedangkan untuk menentukan tingkat efektivitas pembelajaran fisika digunakan formula $\mathrm{N}_{\text {gain }}$ yaitu Perbandingan antara selisih Posttes dan pretes dengan selisih Nilai maksimum dan pretes yang di formulasikan sebagai berikut

$$
N_{\text {gain }}=\frac{\left(X_{2}-X_{1}\right)}{\left(X_{3}-X_{1}\right)} \quad \text { (sugiyono, 2017) }
$$

Besaran $X_{1}, X_{2}, X_{3}$ masing-masing adalah sebagai nilai pre-tes, nilai post-tes dan nilai maksimum, angka $\mathrm{N}_{\text {gain }}$ berkisar antara 0 sampai dengan 1, untuk menentukan tingkat efektivitas penggunaan Program Pembelajaran Fisika Berbasiskan ICT. digunakan kreteria berikut

Tabel 3.1 Kriteria Indeks Gain

\begin{tabular}{cccc}
\hline NoTingkat Efektivitas & $\mathbf{N}_{\text {gain }}$ & Kategori \\
\hline 1 & Sangat efektif & $\geq 0,70$ & Tinggi \\
2 & efektif & $0,30-0,70$ & Sedang \\
3 & Cukup efektif & 0,30 & Rendah \\
\hline
\end{tabular}

Peran Program Pembelajaran Fisika berbasis ICT untuk mengetahui memotivasi belajar, penurunan miskonsepsi dan wadah pengembangan siswa dianalisis dengan kreteria seperti tabel 3.3. Belajar merupakan proses mengkonstruksi pengetahuan, sikap, dan keterampilan oleh diri seseorang, berhasil tidaknya proses mengkonstruksi pada diri seseorang ditentukan/ dipengaruhi oleh seberapa besar keterlibatan inteligensi dalam proses itu.

Tabel 3.3 Kriteria penilaian Pemberian nilai/score peran Program Pembelajaran Fisika Berbasiskan ICT

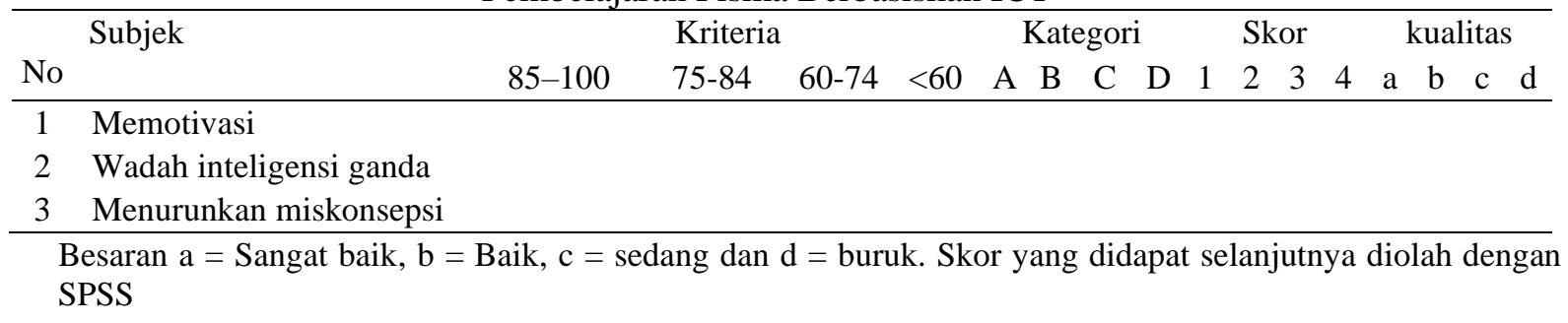


Proses belajar seharusnya dapat memanfaatkan dan mengembangkan semua inteligensi yang dimiliki setiap anak secara optimal. Mengingat inteligensi yang dimiliki siswa satu sama lain telatif berbeda, maka dalam proses pembelajaran perlu variasi yang memungkinkan semua potensi inteligensi anak dapat dimanfaatkan dan dikembangkan. Keberhasilan proses pembelajaran pada hakekat adalah, seberapa jauh proses itu dapat memfasilitasi dan mewadahi pemanfaatan dan pengembangan semua jenis inteligensi siswa dalam mengkonstruksi pengetahuan, sikap, dan keterampilan. Pembelajaran melalui program pembelajaran fisika berbasiskan ICT memberikan hasil belajar fisika yang baik, memotivasi mahasiswa, mewadahi inteligensi ganda dan menurunkan miskonsepsi, hal tersebut dapat dilihat pada table 4.1.

Berdasar tabel 4.1 besar $N_{\text {Gain }}$ dapat dihitung dengan menggunakan formula

$$
N_{\text {Gain }}=\frac{(86,98-26,83)}{(100-26,83)}=\frac{(86,98-26,83)}{(100-26,83)}=\frac{(60,15)}{(73,17)}=
$$

sedangkan Standar deviasi dihitung dengan menggunakan formula

$$
s=\sqrt{\frac{\sum_{i=1}^{n}\left(x_{i}-\bar{x}\right)^{2}}{n-1}}
$$

Besaran $\mathrm{s}=\underline{\text { standar deviasi }}, \mathrm{x}_{\mathrm{i}}=$ nilai $\mathrm{x}$ ke-i, $x=$ skor rata-rata dan $\mathrm{n}=$ ukuran sampel. Berdasar perhitungan menggunakan SPSS didapat skor rata-rata motivasi sebesar 3,88 skor rata-rata inteligensi ganda sebesar 3,94 dan skor rata-rata penurunan miskonsepsi sebesar 3,94. Sedangkan Standar Deviasi hasil belajar Post-tes sebesar 4.164, motivasi sebesar 0.317, inteligensi ganda sebesar 0.231 dan Standar Deviasi penurunan miskonsepsi sebesar 0.231. Hasil penelitian memperlihatkan bahwa, Program Pembelajaran Fisika Berbasiskan ICT efektif digunakan dalam pembelajaran, hal itu terlihat dari nilai $N_{\text {Gain }}$ sebesar 0,82 berada dalam kategori tinggi atau sangat efektif. Belajar menjadi sangat efektif menggunakan Program Pembelajaran Fisika Berbasiskan ICT disebabkan oleh adanya system multimedia yang interaktif sehingga hampir semua panca-indera terlibat dalam menyerap dan mengkonstruksi pengetahuan.

Pembelajaran menggunakan Program Pembelajaran Fisika Berbasiskan ICT juga memungkinkan mahasiswa bebas dalam belajar, dapat dilakukan kapan saja dan dimana saja serta dilengkapi dengan animasi dan simulasi yang memungkinkan mahasiswa termotivasi dalam belajar.

Kenyamanan dan kemudahan menggunakan menggunakan Program Pembelajaran Fisika Berbasiskan ICT membantu siswa untuk betah dalam belajar, sehingga suasanya yang menyenangkan ini menambah semangat mahasiswa belajar. Disamping itu tampilan yang disuguhkan Program Pembelajaran Fisika Berbasiskan ICT memungkinkan semua jenis inteligensi mahasiswa dapat terwadahi untuk tumbuh dan berkembang secara optimal. hampir semua inteligensi mahasiswa dapat terwadahi, dan terwujudkan dalam program pembelajaran e-learning berbasis ICT, namun wujud yang ada pada dalam program pembelajaran e-learning berbasis ICT belum dapat secara tegas diperuntukkan pada jenis inteligensi tertentu, maksudnya, satu jenis program dapat saja mewadahi beberapa jenis inteligensi, karena memang tidak ada batasan yang tegas tentang jenis inteligensi seseorang. Seseorang dapat saja memiliki beberapa jenis inteligensi, namun tidak semua jenis inteligensi menonjol pada orang tersebut, melainkan hanya sebagian saja, dan untuk setiap orang jenis inteligensinya yang menonjol tidak sama. Secara umum dapat dikatakan bahwa, program pembelajaran elearning berbasis ICT dapat mewadahi tumbuhkembangnya inteligensi ganda secara relatif mudah, efisien, efektif, individual, dan murah.

Tampilan yang disuguhkan Program Pembelajaran Fisika Berbasiskan ICT yang dilengkapi dengan animasi, simulasi, visualisai, demo dan modul analisis serta modul latihan memungkinkan miskonsepsi siswa dapat menurunkan miskonsepsi fisika siswa. Hal ini disebabkan adanya usaha meng"konkrit"kan hal hal yang selama ini dianggap abstrak oleh siswa. Temuan kontribusi program e-learning dalam mengembangkan kecerdasan ganda diperoleh hasil yang sama yang ditemukan di berbagai negara. Para ahli di Thailand menemukan bahwa; indikator dalam model MILA (Kegiatan Pembelajaran Multiple Intelligences) sesuai dan berada dalam kategori yang sangat baik yang digunakan dalam proses pembelajaran (Tangwannawit, et al, 2008). Penelitian Eropa juga menemukan bahwa model pembelajaran jarak jauh dan terbuka yang berisi berbagai kecerdasan Howard Gardner tidak hanya sebagai media untuk menyebarkan pendidikan, tetapi juga bertindak sebagai sarana untuk mencapai tingkat pemahaman dan kesadaran baru, dan juga mencerminkan peran pendidikan (Vieira et al., (2014). Penelitian di Afrika Selatan menemukan bahwa untuk mengoptimalkan 
potensi siswa, pembelajaran dilakukan berdasarkan kecerdasan majemuk (FE Gouws,

Tabel 4.1 Rekapitulasi Skor pretes, postes, motivasi, $\frac{\text { inteligensi ganda, dan penurunan miskonsepsi }}{\text { No }}$

\begin{tabular}{|c|c|c|c|c|c|c|}
\hline & pretes & Postes & $\left(x_{i}-x\right)^{2}$ & $\mathrm{a}$ & $\mathrm{b}$ & $\mathrm{c}$ \\
\hline 1 & 30 & 90 & 9,12 & 4 & 4 & 4 \\
\hline 2 & 13 & 90 & 9,12 & 4 & 4 & 4 \\
\hline 3 & 17 & 80 & 48,72 & 4 & 4 & 4 \\
\hline 4 & 27 & 90 & 9,12 & 4 & 4 & 4 \\
\hline 5 & 40 & 90 & 9,12 & 4 & 4 & 4 \\
\hline 6 & 17 & 87 & 0,4 & 4 & 4 & 4 \\
\hline 7 & 30 & 87 & 0,4 & 4 & 4 & 4 \\
\hline 8 & 43 & 87 & 0,4 & 4 & 4 & 4 \\
\hline 9 & 20 & 90 & 9,12 & 4 & 3 & 4 \\
\hline 10 & 27 & 80 & 48,72 & 4 & 4 & 4 \\
\hline 11 & 27 & 87 & 0,4 & 4 & 4 & 4 \\
\hline 12 & 23 & 77 & 99,6 & 4 & 4 & 4 \\
\hline 13 & 37 & 90 & 9,12 & 4 & 4 & 4 \\
\hline 14 & 30 & 90 & 9,12 & 4 & 4 & 4 \\
\hline 15 & 30 & 90 & 9,12 & 4 & 4 & 4 \\
\hline 16 & 20 & 90 & 9,12 & 3 & 4 & 4 \\
\hline 17 & 20 & 90 & 9,12 & 3 & 4 & 3 \\
\hline 18 & 33 & 83 & 15,84 & 4 & 4 & 4 \\
\hline 19 & 30 & 83 & 15,84 & 4 & 4 & 4 \\
\hline 20 & 37 & 90 & 9,12 & 4 & 4 & 4 \\
\hline 21 & 30 & 90 & 9,12 & 4 & 4 & 4 \\
\hline 22 & 30 & 80 & 48,72 & 4 & 4 & 4 \\
\hline 23 & 20 & 90 & 9,12 & 4 & 4 & 4 \\
\hline 24 & 20 & 90 & 9,12 & 4 & 4 & 4 \\
\hline 25 & 33 & 87 & 0,4 & 4 & 4 & 4 \\
\hline 26 & 30 & 87 & 0,4 & 4 & 4 & 4 \\
\hline 27 & 13 & 87 & 0,4 & 4 & 3 & 4 \\
\hline 28 & 17 & 90 & 9,12 & 4 & 4 & 4 \\
\hline 29 & 27 & 80 & 48,72 & 4 & 4 & 4 \\
\hline 30 & 40 & 87 & 0,4 & 4 & 4 & 4 \\
\hline 31 & 17 & 77 & 99,6 & 4 & 4 & 4 \\
\hline 32 & 30 & 90 & 9,12 & 4 & 4 & 4 \\
\hline 33 & 43 & 90 & 9,12 & 4 & 4 & 4 \\
\hline 34 & 20 & 90 & 9,12 & 3 & 4 & 4 \\
\hline 35 & 27 & 90 & 9,12 & 3 & 4 & 3 \\
\hline 36 & 27 & 90 & 9,12 & 4 & 4 & 4 \\
\hline 37 & 23 & 83 & 15,84 & 4 & 4 & 4 \\
\hline 38 & 37 & 83 & 15,84 & 4 & 4 & 4 \\
\hline 39 & 30 & 90 & 9,12 & 4 & 4 & 4 \\
\hline 40 & 30 & 90 & 9,12 & 4 & 4 & 4 \\
\hline 41 & 20 & 80 & 48,72 & 4 & 4 & 4 \\
\hline 42 & 20 & 90 & 9,12 & 4 & 4 & 4 \\
\hline 43 & 30 & 90 & 9,12 & 4 & 4 & 4 \\
\hline 44 & 13 & 87 & 0,4 & 4 & 4 & 4 \\
\hline 45 & 17 & 87 & 0,4 & 4 & 3 & 4 \\
\hline 46 & 27 & 87 & 0,4 & 4 & 4 & 4 \\
\hline 47 & 40 & 90 & 9,12 & 4 & 4 & 4 \\
\hline 48 & 17 & 80 & 48,72 & 4 & 4 & 4 \\
\hline 49 & 30 & 87 & 0,4 & 4 & 4 & 4 \\
\hline 50 & 43 & 77 & 99,6 & 4 & 4 & 4 \\
\hline 51 & 20 & 90 & 9,12 & 4 & 4 & 4 \\
\hline 52 & 27 & 90 & 9,12 & 3 & 4 & 4 \\
\hline 53 & 27 & 90 & 9,12 & 3 & 4 & 3 \\
\hline 54 & 23 & 90 & 9,12 & 4 & 4 & 4 \\
\hline jumlah & 1449 & 4697 & & 210 & 213 & 213 \\
\hline
\end{tabular}

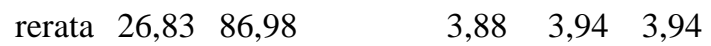

$\begin{array}{lllll}\text { Standar deviasi } \quad 4.164 & 0.31 & 0.23 & 0.23\end{array}$

2008). Temuan ini juga sejalan dengan penelitian lain yang mengatakan bahwa kecerdasan ganda memiliki dampak pada kegiatan e-learning yang ketat untuk integrasi berbagai kecerdasan dengan model e-learning (Kunjal Barataratumar Mankad, 2015). Semua jenis kecerdasan dapat tumbuh dan berkembang secara optimal dalam proses pembelajaran ketika diterapkan dan didukung program e-Learning (Christopher Pappas, 2005).

Temuan di atas sejalan dengan temuan lain yang menunjukkan; project requirement yang menggunakan model Product-Service System (PSS) untuk menentukan roadmap pembangunan Virtual Classroom secara keseluruhan berjalan dengan baik dan layak untuk dilaksanakan (Risnandar, 2010). Selanjutnya Riset tentang penggunaan Interactive 3D E-Learning di SMP No.151 dan MTs No.77B/95 Bandung menunjukkan bahwa Interactive $3 D$ E-Learning disukai dan sangat disukai $(\mathrm{S}+\mathrm{SS})$ untuk digunakan sebagai media pembelajaran $74 \%$, meningkatkan kemampuan kognitif $83 \%$, menarik dan mudah digunakan $77 \%$, memotivasi dan menarik minat belajar 78\% (Sianipar, 2010). Seiring temuan riset di atas akhir-ahkir ini ditandai oleh adanya format belajar berbentuk Cyber (e-learning) melalui komputer dan internet (Sehat Sempurna., 2012).

Aktivitas dan prestasi belajar mahasiswa pada mata kuliah analisis real berbasis web dalam bentuk e-learning meningkat, dan ketuntasan belajar mahasiswa tercapai sebesar 92,5\% (Dian Kurniati,Dinawati Trapsilasiwi, 20014). Skor Keefektivitas e-learning sebagai perencanaan $(77,57 \%)$, pembuatan materi $(75,14 \%)$, penyampaian materi $(66,14 \%)$, interaksi $(75 \%$,$) , evaluasi (69,01 \%$,$) , dan media$ pembelajaran sebaesar 77,27\% (Numiek SH, 2013). Mahasiswa JPTE PT UNM termotivasi dalam pembelajaran Instalasi Listrik 2 yang menggunakan animasi adobe flash cs3 pada kategori baik (75\%)(Hasrul, 2011). Pembelajaran Biologi menggunakan elearning berbasis multiple intelligences pada system gerak manusia, Menunjukan hasil belajar meningkat sebesar $21 \%$ dan ketuntasan belajar mencapai $100 \%$, sehingga proses pembelajaran mahasiswa menjadi efektif (Isni Murdiyani, 2012).

E-learning sebagai media pembelajaran interaktif berbasis Teknologi Informasi, menunjukan bahwa E-learning sebagai media 
pembelajaran interaktif berbasis Teknologi Informasi diwujudkan dalam bentuk modul yang memuat konten guru yang meliputi soal, pengumuman, upload materi ajar, memriksa, dan mengumumkan hasil ujian, serta konten siswa meliputi melihat pengumuman, hasil ujian dan men-download materi ajar (M. Yazdi, 2012). Sistem e-learning untuk meningkatkan proses belajar-mengajar pada SMA N 10 Bandar Lampung, Hasil penelitian memutuskan dibangun system e-learning Learning Management System yang menggunakan analisa ANP (Novi Hidayati, 2010).

Pengembangan Metode Pembelajaran Online Berbasis E-learning pada mata kuliah Pemrograman Teknik Komputer IPB Bogor, menunjukan Pengembangan Metode Pembelajaran Berbasis E-learning dapat dilasnakan dengan baik jika didukung oleh sarana dan prasarana jaringan, serta sosialisai metode tersebut pada civitas akademika di Direktorat Program Diploma IPB (Budi, Brian Nurjayanti, 2012). E-elarning cerdas dengan personalisasi menggunakan teknik data mining dan decision support system pada elearning-ujb.net menyimpulkan; Teknik data mining dan system pengambil keputusan dapat digunakan dalam merekomendasikan bahan ajar, buku, materi kuliah, jurnal yang sesuai dengan minat pengguna situs elearning-ujb.net (Agus S.A, 2010). elearning moodle layak digunakan dengan hasil kelayakan e-learning menurut pakar masuk katagori baik 3,98, menurut ahli media termasuk katagori baik dengan skor 3,98, berdasarkan uji beta termasuk katagori sangat baik dengan skor 4,15 , uji produk termasuk kategori baik dengan skor 3,90 dan efektif meningkatkan hasil belajar siswa sebesar 13,24 (Zyainuri, Eko.Marpanaji; 2012).

Elearning berbantuan virtual laboratory valid untuk digunakan dibuktikan dengan nilai skor para ahli untuk aspek materi sebesar $91,67 \%$, aspek media sebesar $96,75 \%$. Skor angket mahasiswa untuk praktikum online $81,30 \%$, untuk tahap small group $81,50 \%$, dan virtual laboratory sangat praktis digunakan (Dwi Agustine, Ketang Wiyono, M. Muslim., 2014).

Penerapan Blended Learning dengan Numbered Heads Together (NHT) untuk meningkatkan minat dan prestasi belajar pada materi kelarutan dan hasil kali kelarutan di SMA N Gondangrejo, Penelitian ini menujukan bahwa; minat siswa meningkat dari $73,37 \%$ menjadi $78,93 \%$, ketuntasan belajar meningkat dari $50,00 \%$ menjadi $79,17 \%$, sedangkan psikomotor tercapai $79,17 \%$. (Jatmiko BP, J.S Sukarjo, Sri Mulyani; 2013). Temuan lain menunjukan bahwa Penggunaan Program elearning dalam pembelajaran dapat memotivasi siswa belajar (Mayub A., 2015), Penggunaan Program elearning dalam pembelajaran dapat berperan secara baik (Mayub A., 2016), Penggunaan Program elearning dalam pembelajaran dapat Menurunkan miskonsepsi siswa secara signifikan (Mayub A., 2017). Penggunaan Program elearning dalam pembelajaran dapat menjadi wadah bagi berkembangnya inteligensi ganda (Mayub A., 2018).

\section{KESIMPULAN}

Program Pembelajaran Fisika Berbasiskan ICT efektif digunakan dalam pembelajaran hal itu terlihat dari nilai $N_{\text {Gain }}$ sebesar 0,82 berada dalam kategori tinggi atau sangat efektif. Program Pembelajaran Fisika Berbasiskan ICT efektif digunakan untuk memotivasi siswa belajar hal itu terlihat dari score motivasi sebesar 3,88 (dari Skala 1-4) berada dalam kategori sangat baik. Program Pembelajaran Fisika Berbasiskan ICT efektif digunakan sebagai wadah tumbuh-kembangnya inteligensi ganda mahasiswa, hal itu terlihat dari score tumbuhkembangnya sebesar 3,94 (dari Skala 1-4) berada dalam kategori sangat baik. Program Pembelajaran Fisika Berbasiskan ICT efektif digunakan untuk menurunkan miskonsepsi mahasiswa, hal itu terlihat dari score penurunan miskonsepsi sebesar 3,94 (dari Skala 1-4) berada dalam kategori sangat baik

\section{DAFTAR PUSTAKA}

Agus S.A. 2010. E-elarning cerdas dengan personalisasi menggunakan teknik data mining dan decision support system pada elearning-ujb.net Univ. Janabadra, Ykt, Seminar Nasional Informatika 2010, Yogyakarta 2010; ISSN 1979-2328.

Budi, Brian Nurjayanti. 2012. Pengembangan Metode Pembelajaran Online Berbasis Elearning pada mata kuliah Pemrograman Teknik Komputer IPB Bogor, Jurnal Sains Terapan Edisi II Vol.2 No.1 Hal 103-113, 20012.

Christopher Pappas. (2005) Multiple Intelligences In eLearning: The Theory and Its Impact, e-learning industry

DePorter and Hernacki. (2011). Differences in Learning Method Using Quantum Learning 
Flash Animation with Conventional Learning on The Concept of Temperature and Heat, Google Translate for Business: Translator Toolkit Website Translator Global Market Finder.

Dian Kurniati, Dinawati Trapsilasiwi. 2014. Pengembangan model Pembelajaran analisis real berbasis web dalam bentuk e-learning; @Kadikma, Vol.5, No.3, hal $1-12$

Dwi Agustine, Ketang Wiyono, M. Muslim. 2014. Pengembangan elearning berbantuan virtual laboratory untuk mata kuliah praktikum fisika dasar II di program studi pendidikan fisika FKIP UNSRI, Jurnal Inovasi dan Pembelajaran Fisika Vol.1 No.1

FE Gouws. (2008). Journal Teaching and learning through multiple intelligences in the outcomes-based education classroom, Africa Education Review, Volume 4.

Haryono. (2012). Virtual Learning/Virtual Classroom, Sebagai model pendidikan jarak jauh: Konsep dan penerapannya, Seminar Nasional Teknologi Pembelajaran, Balai Besar Pengembangan Teknologi Tepat GunaLIPI.

Hasrul, 2011. Desain Media Pembelajaran Animasi berbasis Adobe Flash CS3 pada mata kuliah intalasi listrik 2, Jurnal Medtek, Vol.3 No.2 Oktober 2011.

Ishafit. 2014. Pengembangan Pembelajaran fisika dengan multiple Representations Berbasis ICT untuk meningkatkan Penguasan Konsep Kinematika, Persepesi, dan motivasi Mahasiswa PGMIPA-BI, Prosideding Pertemuan Ilmiah XXVIII HFI Jateng \& DIY, Yogyakarta, April 2014.ISSN 08530823.

Isni Murdiyani, 2012. Pembelajaran Biologi menggunakan elearning berbasis multiple intelligences pada system gerak manusis, Journal of Curriculum and Educational, Vo.1, No.1, 2012, ISSN 2252-7125.

Jatmiko BP, J.S Sukarjo, Sri Mulyani, 2013. Penerapan Blended Learning dengan Numbered Heads Together (NHT) untuk meningkatkan minat dan prestasi belajar pada materi kelarutan dan hasil kali kelarutan di SMA N Gondangrejo, 2013, Jurnal Pendidikan Kimia Vol.2 No.4 Thn 2013, ISSN 2337-9995

Kunjal Bharatkumar Mankad. (2015). The Role of Multiple Intelligence in E-
Learning, IJSRD - International Journal for Scientific Research \& Development| Vol. 3, Issue 05, 2015 | ISSN (online): 2321-0613

Laela Halawi. (2010). Belajar Efektif Dengan ELearning Faculty of Human Sciences, Waseda University and Faculty of Education, Nagasaki University, Japan

M. Yazdi. (2012). E-learning sebagai media pembelajaran interaktif berbasis Teknologi Informasi, Jurnal Ilmiah Foristek Vol.2, No.1, Maret 2012

M. Yazdi. 2012. E-learning sebagai media pembelajaran interaktif berbasis Teknologi Informasi, Jurnal Ilmiah Foristek Vol.2, No.1, Maret 2012.

Mayub, 2015. Implementasi Virtual Classroom Sebagai Upaya Memotivasi Mahasiswa Belajar Fisika, Laporan Penelitian 2015

Mayub, 2016. Analisis peran e-learning dalam pembelajaran Fisika Dasar Laporan Penelitian 2016

Mayub, 2017. Rekayasa Model Program Elearning Sebagai Wadah Perbaikan Miskonsepsi Fisika Pada Mahasiswa, Laporan Penelitian 2017

Mayub, 2018. Menumbuhkembangkan Inteligensi Ganda melalui Program Elearning Berbasiskan ICT, Laporan Penelitian 2018

Medeiros Vieira, Leandro and Ferasso, Marcos and Schröeder, Christine, (2014). Connecting Multiple Intelligences through Open and Distance Learning: Going towards a Collective Intelligence? European Journal of Open, Distance and E-Learning, Volume 17, Issue 1, Jul 2014. Available at SSRN: https://ssrn.com/ abstract $=2875482$

Morten Brekke, Peter Henrik Hosstad. 2010. New Teaching Method-Using computer technology in physics, mathematics and compoter science, International Journal of digital Society, Volume 1, issue 1, March, p. 19

Mustadji. 2011. Pemanfaatan Multimedia Untuk Meningkatkan kualitas Pendidikan, seminar AKAL interaktif di TB., Gramedia EXSPO Surabaya

Novi Hidayati. 2010. Sistem e-learning untuk meningkatkan proses belajar-mengajar pada SMA N 10 Bandar Lampung, Jurnal Telematika Mkom Vol.2, No.2, 2010

Numiek SH. 2013. Keefektivitas e-learning sebagai media pembelajaran di SMK Telkom Sandhy Putra Purwokerto, Jurnal Pendidikan Vokasi, Vol.3 No.1 Februari 20013 
Purbo O.W., Hartanto, A.A. 2001. Teknologi e-Learning, PT Elex Media Komputindo, Jakarta.

Risnandar. 2010. Perancangan e-learning dengan Pendekatan Product-Service System (PSS) dan DICE Framework, Konferensi dan Temu Nasional Teknologi Informasi dan Komunikasi untuk Indonesia, Bandung.

Sakchai Tangwannawit, Nidapan Sureerattanan, Monchai Tiantong. (2008). Multiple Intelligences Learning Activities Model in e-Learning Environment Department of Computer Education King Mongkut's University of Technology North Bangkok Thailand

Sehat Sempurna. (2012). Perkembanagn elearning, Jur.Teknik Komputer dan jaringan ITB-SEOMOLEC, Bandung.

Sianipar DB. (2010). Desain dan Pengembangan Interactive 3 Dalam Meningkatkan Kemampuan Kognitif Siswa, Laporan Penelitian, Magister Teknik Elektro ITB, Bandung.
Sugiyono. (2017). Metode Penelitian Kuantitatif, Kualitatif, dan R\&D. Bandung: Alfabeta, CV.

Sulistyo, J. 2010. 6 hari jago SPSS 17, Cakrawala, Yogyakarta

Sutrisno. 1993. Fisika Komputasi dan Kurikulum Inti Pendidikan Sarjana Fisika dan Sarjana Pendidikan Fisika, Jurusan Fisika ITB, Bandung.

Team E-learning. 2004. Buku Panduan WebCT 4.1 Untuk Pengajar, Universiteit Utrecht dan Universitas Padjadjaran, Bandung.

Victor. 2008. Pengembangan Prototipe Model Virtual Reality Interaktif, Skipsi, Program Studi Teknik Informatika Sekolah Teknik Elektro dan Informatika Institut Teknologi Bandung, Bandung.

Zyainuri, Eko Marpanaji. 2012. Penerapan elearning moodle untuk pembelajaran siswa yang melaksanakan Prakerin, Jurnal Pendidikan Vokasi, Vol.2 No.3, 2012. 